\title{
Anti-ganglioside antibodies and celiac disease
}

\author{
Alessandro Granito ${ }^{1,2^{*}}$, Francesco Tovoli ${ }^{1,2}$, Alberto Raiteri ${ }^{1,2}$ and Umberto Volta ${ }^{1}$
}

\section{Dear Editor,}

We read with great interest the article by Cutillo et al. analyzing the multiple roles of gangliosides and their key components, sialic acids, in the protection of human and microbial cells from host immune response, and their potential to serve as targets for autoimmunity [1].

In their discussion of anti-ganglioside antibodies and analysis of the various human pathologies in which antiganglioside antibodies have been reported, the authors mention celiac disease (CD) as a condition associated with the presence of anti-GM1 antibodies. They also state that the triggering factor that induces antiganglioside antibodies generation is unknown. However, the authors support the hypothesis that the formation of complexes between gliadin and GM1 ganglioside leads to the generation of antibodies to GM1 as a "secondary product". In this respect, $\mathrm{CD}$ can be considered an autoimmune disease where, unusually, several pathogenetic factors are well known, i.e., the extrinsic trigger (gliadin), a close genetic background (HLA-DQ2 or -DQ8), and a highly specific immune response directed to a well-characterized autoantigen (tissue transglutaminase). Our data on the presence of antineuronal antibodies to central/enteric nervous systems provide further support for the autoimmune hypothesis of neurological dysfunction in CD patients [2-4].

We have previously described in 2006 our own experience on the prevalence of a wider range of

\footnotetext{
*Correspondence: alessandro.granito@unibo.it

${ }^{1}$ Department of Medical and Surgical Sciences, University of Bologna, Bologna, Italy
}

Full list of author information is available at the end of the article anti-ganglioside antibodies and their clinical significance in $\mathrm{CD}$ patients $[5,6]$.

Using a commercially available ELISA kit (IMMCO Diagnostics, Buffalo, NY, USA), we studied anti-GM1, anti-GD1b, and anti-GQ1b serum IgG and IgM antibodies in 22 adult patients (median age 35, range: 19-56 years; three males, 19 females) with CD and neurological manifestations, including eight cases of idiopathic cerebellar ataxia, seven cases with epilepsy (without cerebral calcifications), two with multiple sclerosis, three with attention/memory impairment, and two with peripheral neuropathies.

In all cases, diagnosis of $\mathrm{CD}$ was confirmed by endoscopic duodenal biopsy, revealing different grades of villous atrophy (from 3a to 3c, according to the modified Marsh classification). In all CD patients, intestinal villous atrophy was associated with a positivity for serological CD markers (anti-endomysial and/or antitissue transglutaminase antibodies) further supporting the diagnosis of $\mathrm{CD}$. All available data, regarding $\mathrm{CD}$ diagnosis, diagnostic work-up, histopathology and treatment were obtained from the hospital digital database.

In addition, anti-ganglioside antibodies status was assessed in 30 patients with CD without neurological dysfunction (median age 37 years, range $17-59$ years, eight males, 22 females), 20 patients with neurological disorders (seven with idiopathic cerebellar ataxia, seven with epilepsy, four with peripheral neuropathy, one with paraneoplastic syndrome and subacute cerebellar atrophy, and one with amyotrophic lateral sclerosis), 50 patients with immune system disorders (six with Crohn's disease, four with ulcerative colitis, 10 with autoimmune hepatitis, 20 with primary biliary

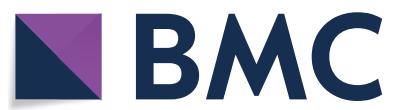

(c) The Author(s) 2021. This article is licensed under a Creative Commons Attribution 4.0 International License, which permits use, sharing, adaptation, distribution and reproduction in any medium or format, as long as you give appropriate credit to the original author(s) and the source, provide a link to the Creative Commons licence, and indicate if changes were made. The images or other third party material in this article are included in the article's Creative Commons licence, unless indicated otherwise in a credit line to the material. If material is not included in the article's Creative Commons licence and your intended use is not permitted by statutory regulation or exceeds the permitted use, you will need to obtain permission directly from the copyright holder. To view a copy of this licence, visit http://creativeco mmons.org/licenses/by/4.0/. The Creative Commons Public Domain Dedication waiver (http://creativecommons.org/publicdomain/ zero/1.0/) applies to the data made available in this article, unless otherwise stated in a credit line to the data. 
cholangitis, and 10 with the calcifications, Raynaud's phenomenon, esophageal hypomotility, sclerodactyly, and telangiectasia (CREST) syndrome, and 20 blood donors with comparable age and sex demographics. The study was approved by the local Ethics Committee and all patients and controls gave their informed consent before.

Our anti-ganglioside antibodies assessment results are summarized in Fig. 1. At least one of the three antiganglioside IgG antibodies tested for (anti-GM1, antiGD1b, anti-GQ1b) was found in $64 \%$ of CD patients with neurological dysfunction compared to $30 \%$ of CD patients without neurological symptoms, $50 \%$ of neurological patients without CD, $20 \%$ of autoimmune controls and none of the healthy controls $(p=0.02$, $\mathrm{p}=\mathrm{ns}, \mathrm{p}=0.003$ and $\mathrm{p}=0.0001$, respectively).

Analysis of individual reactive antibody types showed that both anti-GM1 and anti-GD1b IgG were significantly more frequent in $\mathrm{CD}$ patients with neurological dysfunction than in $\mathrm{CD}$ patients without neurological symptoms, autoimmune controls, and blood donors. No significant difference between groups was found for antiGQ1b IgG.

Among the neurological patients with $\mathrm{CD}$, six of the seven with epilepsy, two of the three with attention deficit/memory impairment syndrome, three of the eight with idiopathic cerebellar ataxia, one of the two with multiple sclerosis, and both patients with peripheral neuropathy had anti-ganglioside IgG antibodies.

Of these 14 patients, 11 showed reactivity against only one ganglioside, two showed reactivity to two gangliosides, and one patient showed reactivity to all three gangliosides. Within the group with neurological disorders but without CD, four of the seven with idiopathic cerebellar ataxia, four of the seven with epilepsy, and two of the four with peripheral neuropathy were positive for IgG antibodies to gangliosides.

In patients with autoimmune diseases, anti-ganglioside antibodies were found in three of the six with Crohn's disease, one of the four with UC, two of the 10 with $\mathrm{AIH}$, two of the 20 with PBC, and two of the 10 with CREST syndrome.

Ganglioside reactivity, expressed in terms of Enzymatic Units (AEU) associated with anti-GM1 and anti-GD1b IgG were significantly higher in CD patients with neurological disorders (anti-GM1: median 20.35 AEU, range 2.6-136.5 AU; anti-GD1b: median 16.5 AEU, range 5.9-79.4 AEU) than in CD patients without neurological disorders (anti-GM1: median 16.2 AEU, range 5.9-35.5 AEU; anti-GD1b: median 12.05 AEU, range 5.9-33.1 AEU) ( $\mathrm{p}=0.04$ and $\mathrm{p}=0.02$, respectively), autoimmune control patients (anti-GM1: median 13.1 AEU, range 5.3-41.2 AEU; anti-GD1b: median 11.1 AEU, range 5.9-33.1 AEU) Neurological CD Neurological controls

Non-neurological CD

Autoimmune controls

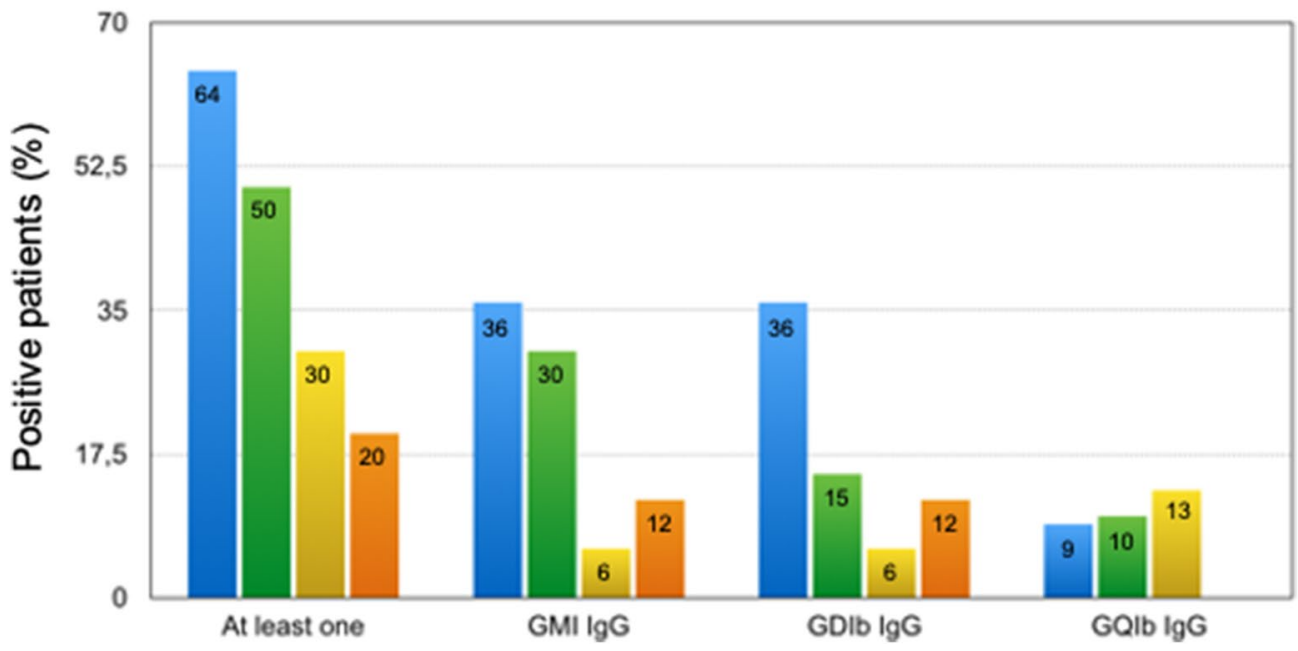

Fig. 1 Immunoglobulin G (lgG) antibodies to GM1, GD1b, and GQ1b, expressed as the percentage of patients in each study population that was positive for at least one lgG antibody: CD with a neurological disorder vs CD without neurological disorder, control group with a neurological disorder, and control group with an autoimmune disorder: $p=0.02, p=n s$, and $p=0.003$, respectively. GM1 lgG: CD with a neurological disorder vs $C D$ without neurological disorder, control group with a neurological disorder, and control group with an autoimmune disorder: $p=0.01, p=n s$, $p=0.02$ respectively. GD1 b lgG: CD with a neurological disorder vs CD without neurological disorder, control group with a neurological disorder, and control group with an autoimmune disorder: $p=0.01, p=n s, p=0.02$, respectively. GQ1 b lgG: No significant difference was found; Fisher's exact test 
( $\mathrm{p}=0.007$ and $\mathrm{p}=0.02$, respectively) and healthy blood donors (anti-GM1: median 12.5 AEU, range 5.0-24.0; anti-GD1b: median 9.4 AEU, range 1.1-18.0 AEU) $(\mathrm{p}=0.009$ and $\mathrm{p}=0.0001$, respectively).

No correlation was found between AEU of antibodies to gangliosides and the severity of villous atrophy. Of note, 8 (47\%) of the 17 patients with $C D$ and neurological manifestations who were positive for at least one antiganglioside IgG antibody became negative for the antibody after 1 year of strict adherence to a gluten-free diet.

Interestingly, anti-ganglioside IgM antibodies, although at a lower prevalence than anti-ganglioside IgG antibodies and without any significant difference among the various groups studied, were confined to three cases of epilepsy within the CD group with neurological dysfunction.

CD patients without neurological manifestations, as expected, during follow-up under gluten free diet tested negative for autoantibody markers of $\mathrm{CD}$ and exhibited no other autoantibodies.

The first description of anti-ganglioside antibodies in CD patients dates back to 2002 by Alaidini et al. who reported a positivity for at least one autoantibody directed against GM1, GM2, GD1a, GD1b, GT1b, and GQ1b gangliosides in $6 \mathrm{CD}$ patients with peripheral neuropathy, thus assuming that neuropathy of $C D$ may be autoimmune and associated with anti-ganglioside antibodies [7].

After our 2006 study, other authors confirmed the presence of anti-ganglioside antibodies in celiac disease and their potential pathogenetic role in other autoimmune and non-autoimmune neurological disorders (Table 1).

Interestingly, a molecular mimicry between some microbial antigens, such as lipo-oligosaccharides of Campylobacter jejuni and the gangliosides has been hypothesized as a possible mechanism by which

Table 1 Prevalence of antiganglioside antibodies in celiac disease and other autoimmune and non-autoimmune diseases

\begin{tabular}{|c|c|c|c|}
\hline Study (reference) & Disease & $\begin{array}{l}\text { Anti-ganglioside antibodies } \\
\text { tested }\end{array}$ & Prevalence (\%)/clinical significance \\
\hline $\begin{array}{l}\text { Cats EA et al. } 2010 \\
\text { (Neurology; } 75: 1961-1967 \text { ) }\end{array}$ & MMN & $\begin{array}{l}\text { IgG, and IgA antibodies to GM1, } \\
\text { GM2, GD1a, GD1b, GM1b, GT1a, } \\
\text { GT1b, GQ1b, } \\
\text { GalNAc-GD1a }\end{array}$ & $\begin{array}{l}\text { Anti-GM1^: } \\
\operatorname{lgM}: 43 \% \\
\operatorname{lgG:} 1 \% \\
\operatorname{lgA}: 5 \%\end{array}$ \\
\hline $\begin{array}{l}\text { Lucchetta M et al. } 2010 \\
\text { (Muscle Nerve; 41:50-53) }\end{array}$ & Type 1 Diabetes & $\begin{array}{l}\text { IgG or lgM antibodies to } \\
\text { GM1, GM2, GM3, GD1b, GD1a, GD3 }\end{array}$ & 24\% (one or more gangliosides) \\
\hline $\begin{array}{l}\text { Mostafa GA et al. } 2011 \\
\text { (J Neuroinflammation; 8:39) }\end{array}$ & Autistic children & Anti-ganglioside M1 & $74 \% *$ \\
\hline $\begin{array}{l}\text { Labrador-Horrillo M et al. } 2012 \\
\text { (Lupus.;21:611-615) }\end{array}$ & $\begin{array}{l}\text { SLE with neuropsychiatric } \\
\text { manifestations }\end{array}$ & $\begin{array}{l}\text { GM1, GM2, GM3, asialo-GM1 GD1a, } \\
\text { GD1b, GD3, GT1b, GQ1b }\end{array}$ & $\begin{array}{l}\text { 15\% IgM asialo-GM1, 6\% positive for } \\
\text { other anti-ganglioside antibodies } \\
\text { (GM1, GM2, GM3, GD1b, GT1b, GD3, } \\
\text { mainly IgM) }\end{array}$ \\
\hline $\begin{array}{l}\text { Kim JK et al. } 2014 \\
\text { (J Clin Neurol; 10:94-100) }\end{array}$ & GBS & $\begin{array}{l}\text { IgG and IgM antibodies to } \\
\text { gangliosides GM1, GM2, GM3, } \\
\text { GD1a, GD1b, GD3, GT1a, GT1b, } \\
\text { and GQ1b }\end{array}$ & $\begin{array}{l}\text { 50\% positive for lgG or lgM } \\
\text { antibodies against various } \\
\text { gangliosides }\end{array}$ \\
\hline $\begin{array}{l}\text { Kollewe K et al. } 2015 \\
\text { (PLoSOne; 10:e0125339) }\end{array}$ & Amyotrophic Lateral Sclerosis & $\begin{array}{l}\text { IgG and IgM antibodies to asialo1 } \\
\text { (GA1), GM1, GM2, GD1a, GD1b, } \\
\text { GQ1b }\end{array}$ & $\begin{array}{l}\text { lgG: } 10.7 \% \\
\text { IgM: } 17.9 \%\end{array}$ \\
\hline $\begin{array}{l}\text { Ge S et al. } 2016 \\
\text { (Diabetes Res Clin Pract; 115:68-75) }\end{array}$ & Diabetic peripheral neuropathy & $\begin{array}{l}\text { Anti-GS IgM } \\
\text { anti-GS IgG }\end{array}$ & $\begin{array}{l}\text { anti-GS Ab levels positively correlated } \\
\text { with DPN }\end{array}$ \\
\hline $\begin{array}{l}\text { Przybylska-Feluś M et al. } 2016 \\
\text { (Pol Arch Med Wewn; 126:763-771) }\end{array}$ & Celiac disease & Anti-GM1 & $\begin{array}{l}\text { Significantly higher median level of } \\
\text { anti-GM1 antibodies than controls }\end{array}$ \\
\hline $\begin{array}{l}\text { Saccomanno D et al. } 2017 \\
\text { (Scand J Gastroenterol; 52:409-413) }\end{array}$ & Celiac disease & $\begin{array}{l}\text { IgM, IgG, and IgA to GM1, GM2, } \\
\text { GM3, GD1a, GD1b, GD3, GT1a, } \\
\text { GT1b, GQ1b, sulfatide }\end{array}$ & Anti-sulfatide lgG antibodies (36\%) \\
\hline
\end{tabular}

Anti-GS IgM Ab and anti-GS IgG Ab: anti-ganglioside IgM and IgG antibodies, DPN diabetic peripheral neuropathy, GBS Guillain-Barré syndrome, SLE systemic lupus erythematosus, $M M N$ multifocal motor neuropathy

* Serum levels of anti-ganglioside M1 antibodies were significantly higher in autistic children with severe autism (63\%) than those with mild to moderate autism (37\%), $\mathrm{p}=0.001$. Moreover, serum anti-ganglioside M1 antibodies had significant positive correlations with Childhood Autism Rating Scale

$\wedge$ Patients with MMN with anti-GM1 IgM antibodies had more severe weakness $(p<0.01)$, more disability $(p<0.01)$, and more axon loss $(p=0.05)$ than patients without anti-GM1 IgM antibodies. Anti-GM1 IgM antibody titers correlated with Medical Research Council scores (correlation coefficient $=0.43 ; \mathrm{p}<0.0001)$. Anti-GD1b IgM antibody activity was associated with reduced vibration sense $(p<0.01)$

$\S 1.38 \mathrm{ng} / \mathrm{ml}[0.98-2.03 \mathrm{ng} / \mathrm{ml}] \mathrm{vs} 0.81 \mathrm{ng} / \mathrm{ml}[0.35-1.15 \mathrm{ng} / \mathrm{ml}],(\mathrm{p}<0.001$, the Mann-Whitney test) 
anti-ganglioside antibodies are generated, thus reflecting an abnormal immune response to microbiota antigens $[8$, 9].

Our results, which detected anti-ganglioside antibodies beyond anti-GM1, confirm and expand upon previously identified antineuronal antibodies (e.g., Hu-like and Yo-like detected by indirect immunofluorescence) in patients with $\mathrm{CD}$ and neurological complications, confirming the hypothesis that anti-ganglioside antibodies may result from an immunological disorder underlying $\mathrm{CD}[2,4,10]$.

In conclusion, our data support data described by Cutillo et al. on a potential pathogenic role of antiganglioside antibodies in immuno-mediated neurological disorders and provide evidence that detection of anti-ganglioside antibodies could indicate associated neurological symptoms in $\mathrm{CD}$ patients. Anti-ganglioside antibodies may therefore represent immunological markers for neurological dysfunction in $\mathrm{CD}$ patients and should be included in the work-up of CD patients.

\section{Abbreviations}

CD: Celiac disease; AEU: Antiganglioside enzymatic units; CREST: The calcifications, Raynaud's phenomenon, esophageal hypomotility, sclerodactyly, and telangiectasia syndrome.

\section{Acknowledgements}

None.

\section{Authors' contributions}

$A G, F T, A R, U V$ analysed and interpreted the patient data. AG was a major contributor in writing the manuscript. All authors read and approved the final manuscript.

\section{Funding}

None.

\section{Availability of data and materials}

Not applicable.

\section{Declarations}

Ethics approval and consent to participate Not applicable.
Consent for publication

All subjects gave their consent to publish clinical data.

\section{Competing interests}

The authors declare that they have no competing interests.

\section{Author details}

${ }^{1}$ Department of Medical and Surgical Sciences, University of Bologna, Bologna, Italy. ${ }^{2}$ Division of Internal Medicine, Hepatobiliary and Immunoallergic

Diseases, IRCCS Azienda Ospedaliero-Universitaria Di Bologna, Bologna, Italy.

Received: 23 June 2020 Accepted: 10 May 2021

Published online: 28 May 2021

\section{References}

1. Cutillo G, et al. Physiology of gangliosides and the role of antiganglioside antibodies in human diseases. Cell Mol Immunol. 2020;17:313-22.

2. Volta $U$, et al. Clinical findings and anti-neuronal antibodies in coeliac disease with neurological disorders. Scand J Gastroenterol. 2002;37:1276-81.

3. Alaedini A, Latov N. Transglutaminase-independent binding of gliadin to intestinal brush border membrane and GM1 ganglioside. J Neuroimmunol. 2006;177:167-72.

4. Cervio E, Volta U, Verri M, et al. Sera of patients with celiac disease and neurologic disorders evoke a mitochondrial-dependent apoptosis in vitro. Gastroenterology. 2007;133:195-206.

5. Volta $U$, et al. Anti-ganglioside antibodies in coeliac disease with neurological disorders. Dig Liver Dis. 2006;38:183-7.

6. Volta $U$, et al. Antibodies to gangliosides in coeliac disease with neurological manifestations. Aliment Pharmacol Ther. 2005;21:291-3.

7. Alaedini A, Green PH, Sander HW, et al. Ganglioside reactive antibodies in the neuropathy associated with celiac disease. J Neuroimmunol. 2002;127:145-8.

8. Godschalk PC, Heikema AP, Gilbert M, et al. The crucial role of Campylobacter jejuni genes in anti-ganglioside antibody induction in Guillain-Barre syndrome. J Clin Invest. 2004;114:1659-65.

9. Perera VN, Nachamkin I, Ung H, et al. Molecular mimicry in Campylobacter jejuni: role of the lipo-oligosaccharide core oligosaccharide in inducing anti-ganglioside antibodies. FEMS Immunol Med Microbiol. 2007:50:27-36.

10. Trivedi R, et al. Autoantibody screening in subacute cerebellar ataxia. Lancet. 2000;356:565-6.

\section{Publisher's Note}

Springer Nature remains neutral with regard to jurisdictional claims in published maps and institutional affiliations.

\footnotetext{
Ready to submit your research? Choose BMC and benefit from:

- fast, convenient online submission

- thorough peer review by experienced researchers in your field

- rapid publication on acceptance

- support for research data, including large and complex data types

- gold Open Access which fosters wider collaboration and increased citations

- maximum visibility for your research: over $100 \mathrm{M}$ website views per year

At BMC, research is always in progress.

Learn more biomedcentral.com/submissions 